\title{
Population status and habitat use of southern right whales in the sub-Antarctic Auckland Islands of New Zealand
}

\author{
Nathalie J. Patenaude and C. Scott Baker \\ School of Biological Sciences, University of Auckland, Private Bag 92019, Auckland, New Zealand \\ Contact e-mail: n.patenaude@auckland.ac.nz
}

\begin{abstract}
In the winters of 1995, 1996 and 1997, research was conducted in the Auckland Islands to evaluate the status of southern right whales in the New Zealand sub-Antarctic. Whales were present in high concentrations each year (maximum count of 146 whales) in a small area on the northeast side of the main island. Cow-calf pairs averaged $12 \%$ (range $9 \%$ to $14 \%$ ) of the total population. Most cow-calf pairs were sighted resting at the surface $(60 \%)$ or travelling $(36 \%)$ and showed a strong preference for shallow $(<20 \mathrm{~m}$ depth) nearshore waters. The ratio of females to males, as determined by molecular sexing using biopsy samples, varied from $54 \%$ to $39 \%$ over the three years but did not differ significantly from 1:1 in any year. Both males and females were found in varying group sizes, with the occurrence of social/sexual activity predominant $(85 \%)$ in groups of three or more whales. Most single whales were found resting (59\%) and occasionally approached the research vessel (19\%). A total of 217 individual whales have been photo-identified over the three years of this study, $24 \%$ of which were resighted more than once in a season and approximately $15 \%$ of which were resighted in more than one year. The high density of whales in Port Ross during winter months, the presence of cow-calf pairs, including newborns, and the frequency of social and sexual activity indicates that the Auckland Islands are a primary wintering habitat for southern right whales in New Zealand waters. However, the low resighting rates within season and documented movement to nearby Campbell Island (290km) suggest that some whales are not resident in the Auckland Islands throughout the season. The rarity of right whales along the main islands of New Zealand and their apparent increase in numbers in the Auckland Islands suggests a major shift in habitat use from pre-exploitation times or the loss of a component of a historically sub-divided stock.
\end{abstract}

KEYWORDS: SOUTHERN RIGHT WHALE; SUB-ANTARCTIC; BREEDING GROUNDS; ABUNDANCE ESTIMATE; SEX RATIO; REPRODUCTION; BEHAVIOUR; HABITAT

\section{INTRODUCTION}

Prior to exploitation, southern right whales (Eubalaena australis) were widely distributed in New Zealand waters and the population is estimated to have included more than 10,000 individuals (Dawbin, 1986). Shore-based whaling was conducted along both the North and South Islands, with peak whaling involving at least 80 stations between 1843-1845 (Dawbin, 1986). In addition, considerable pelagic whaling by Americans occurred offshore near the Chatham Islands (Fig. 1), east of the Kermadec Islands and in the New Zealand sub-Antarctic Islands during the early 1800s (Townsend, 1935). There were also attempts at shore-based whaling in the sub-Antarctic islands with limited success. In 1849 a whaling station was established in Port Ross, Auckland Islands, that closed three years later, having caught only a single whale (Grady, 1986). Another station operated at Campbell Island (52 $\left.33^{\circ} \mathrm{S}, 169^{\circ} 08^{\prime} \mathrm{E}\right)$ from 1909-1913 and caught 63 right whales (Dawbin, 1986). By the end of the $19^{\text {th }}$ century New Zealand southern right whales were considered commercially extinct (Dawbin, 1986).

Although protected from hunting by international agreement since 1935 , recovery of southern right whales has been slow, and sightings along the coast of mainland New Zealand remain infrequent. More than 35 years elapsed between a sighting in 1963 (Gaskin, 1964) and the previous recorded sighting of a right whale along the New Zealand mainland in 1928. In the past 10 years there have been fewer than 30 reported sightings along the coast of New Zealand (N. Patenaude, unpub. data). Despite year-round occupation at the Kermadec Islands (Fig 1A) by the Department of Conservation, right whales have not been sighted there in the last 10 years (C. Roberts, pers. comm.).
In the sub-Antarctic islands, the pattern of recovery has differed. Although the high latitude of these islands is more consistent with known right whale feeding grounds worldwide, sightings of southern right whales in this area in winter months have increased during the last 50 years. Meteorological staff stationed at Campbell Island (Fig. 1A) from 1942 and 1990 consistently recorded sightings of southern right whales during this season. These sightings included social groups and the occasional presence of cow-calf pairs (Gaskin, 1968; Cawthorn, 1978; 1986; 1988; 1993). From 1995-1997, up to 44 whales were seen at one time at Campbell Island (Stewart and Todd, 2001). No calves were sighted during this period.

In comparison with Campbell Island, there have been few reports of right whales in the Auckland Islands until the last two decades. Whether this is because whales were absent or because the islands were rarely occupied by observers over the winter months is unclear. The New Zealand Coastguard occupied the islands year-round from 1942-1945 and did not report the presence of right whales (M. Cawthorn, pers. comm.). There is now little doubt that population growth around the Auckland Islands was slowed or even reversed by the illegal killing of 258 whales by Soviet factory ships from 1950-1970 (Tormosov et al., 1998).

In the early 1980s, the crew of a private yacht reported sighting approximately 75 right whales at the northeast tip (Port Ross) of the Auckland Islands in winter (M. Cawthorn, pers. comm.). More recently, the Royal New Zealand Air Force (RNZAF) surveyed the Islands in July 1993, and reported 42 right whales including three cow-calf pairs in Port Ross (Donoghue, 1995). Following this survey, the University of Auckland and the New Zealand Department of Conservation jointly conducted the first winter scientific expedition to the Auckland Islands in 1995 to investigate the 
status of southern right whales in those waters (Patenaude $e t$ $a l .$, 1998). This work has continued for two additional years. This paper reports on the current abundance and habitat use of southern right whales found in the Auckland Islands sub-Antarctic waters.

\section{MATERIALS AND METHODS}

\section{Study area}

The Auckland Islands are located $460 \mathrm{~km}$ south of mainland New Zealand (50³3'S, $166^{\circ} 15^{\prime}$ E; Fig. 1). The main island (Auckland) is approximately $40 \mathrm{~km}$ long and $25 \mathrm{~km}$ at its widest. The western coast of the main island is exposed and offers no sheltered areas while the eastern coastline is riddled with large embayments. The southern end of the main island forms a deep water harbour bordered by Adams Island. At the northeast end, Port Ross leads southwest into Laurie Harbour and is bordered by Enderby Island to the north.

Research was conducted in and around Port Ross from 17 July-9 August 1995, from 17 July-7 August 1996 and from 17 July-2 August 1997. In all three years, research was conducted from small vessels (4.6-5.2m) powered by outboard motors. Additionally in 1996 and 1997, a chartered motor-sailing vessel provided a second platform from which to conduct research. In 1995, small-boat surveys were conducted in nearby waters off the north and east shores of Auckland main island (Patenaude et al., 1998). A film crew from the TVNZ Natural History Unit worked in parallel with the research team for two weeks in 1996 and collected underwater footage of whale behaviour. On 27 July 1996, a helicopter chartered by the film crew was used to survey the length of the Auckland Islands, including Carnley Harbour, for right whales (Fig. 1B).

\section{Minimum abundance}

To determine the minimum number of southern right whales in Port Ross each winter, combined shore- and boat-based surveys of Port Ross and adjoining areas were conducted, as described by Patenaude (1998). The areas were divided into sectors (Fig. 2A) and all sectors were simultaneously scanned by eye for a period of 10 minutes. The approximate locations of all whales observed at the surface were recorded. Given the short scanning time, and the minimum amount of travelling of the whales (see Results), duplicate sightings are unlikely. An animal was judged to be a calf when the portion of the animal visible at the surface was less than half of the length of an accompanying adult. A sighting was considered to include only one individual unless more than one individual could be counted at the surface within one and a half whale body lengths. Thus, these censuses represent a minimum estimate of the number of whales observed on each occasion.

\section{Photo-identification}

Photographs of callosity patterns, lip ridges and unusual skin pigmentation were collected for individual identification of the whales (Payne et al., 1983; Kraus et al., 1986; IWC, 1990). Photo-identification was conducted from small vessels and at times from the deck or mast of a larger chartered vessel. Photographs were taken with Kodak Tri-X or T-Max black and white film (ISO 400, pushed to 800 or 1600) using a $35 \mathrm{~mm}$ SLR camera equipped with 200-300mm lenses. Effort was directed at photographing the left side of each whale although both sides were photographed when possible. Topside photographs were taken opportunistically from the mast of the larger vessel.

The analysis of photographs was based on the left side only and generally followed methods described by Payne $e t$ al. $(1977 ; 1989)$, although in this case photographs were first sorted by the presence and extent of the lip callosity. All identification photographs were first cross-checked with other individually identified whales from within the same season and then with whales identified from previous seasons. When no match could be made, the whale was added to the catalogue as a new individual. All identified matches or new whales were confirmed by two experienced researchers. Calves were not included in the final photographic catalogue because the true callosity pattern on their heads are often obscured by ectoparasites inhabiting bare skin as well as callosity tissue (Payne et al., 1983).

\section{Biopsy sampling}

Skin and blubber samples for genetic and pollutant analyses were collected using a compound bow with a small biopsy dart similar to that described by Brown et al. (1991). Biopsy
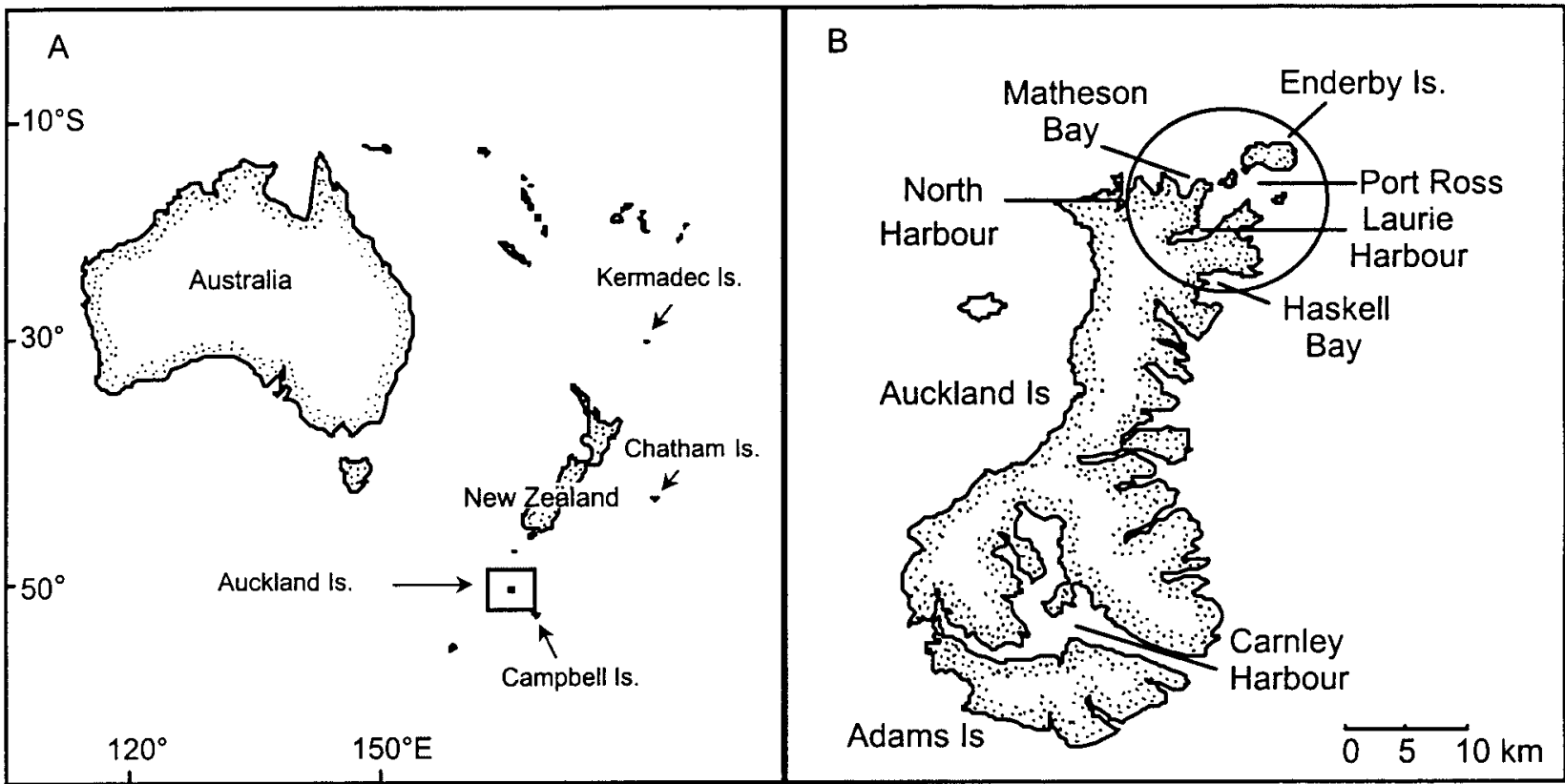

Fig. 1. Location of New Zealand islands (A) and map of the Auckland Islands with area of concentration of southern right whales encircled (B). 


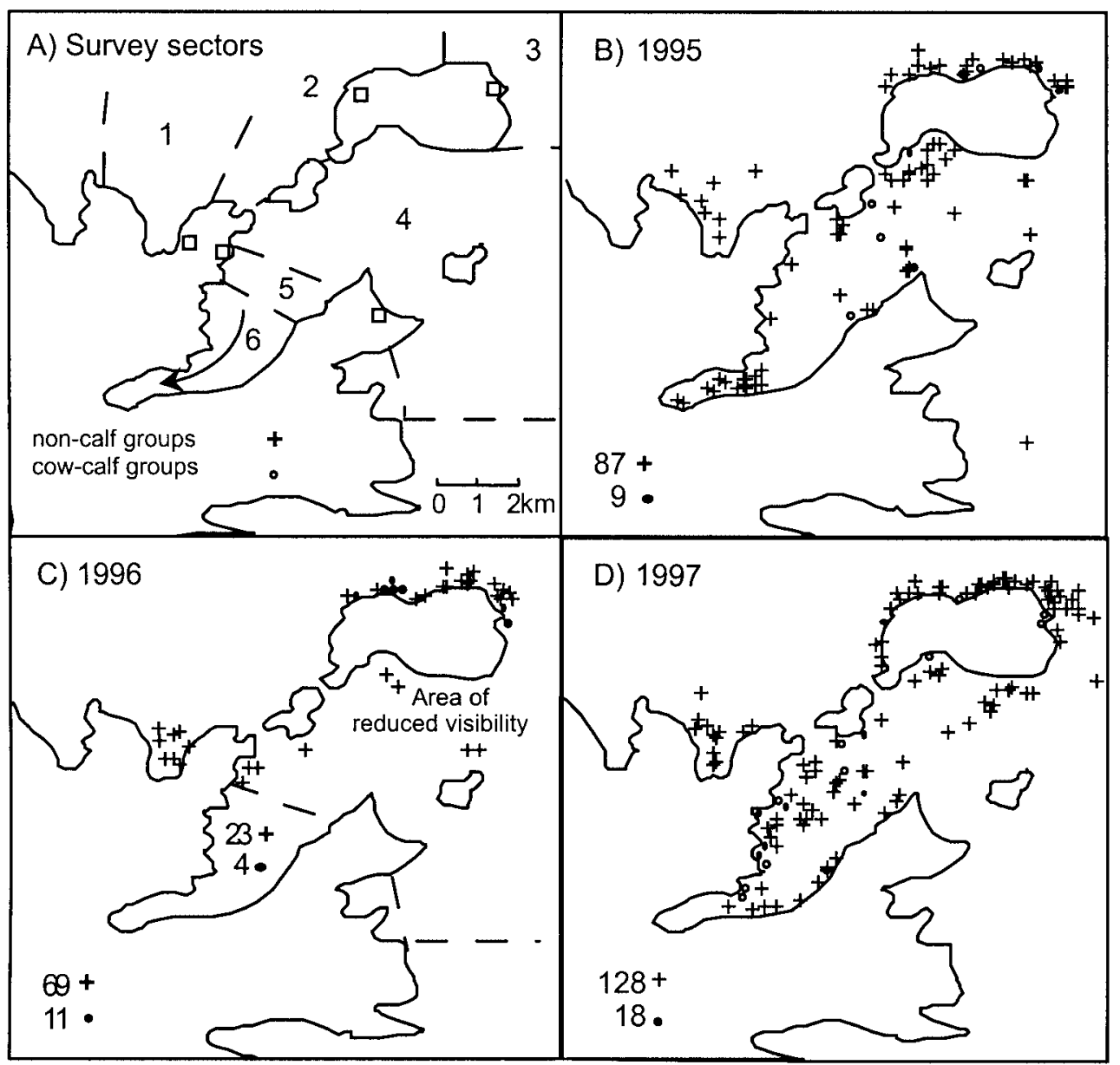

Fig. 2. (A) Map of study area divided into sectors showing shore-based observation points (squares) and path of boat survey (arrow) and location of whale sightings during simultaneous surveys of sector 1-6 in (B) 1995, (C) 1996 and (D) 1997. Location of whales was not recorded during the 1996 boat survey.

samples were collected non-systematically except on specific days when cow-calf pairs were targeted. Skin biopsy samples were stored in $70 \%$ ethanol or frozen in liquid nitrogen. In 1997, a midline slice of epidermis/blubber was stored in $10 \%$ neutral buffered formalin for immuno-histochemical analysis, and blubber samples were separately wrapped in acetone/hexane/methanol rinsed foil and frozen $\left(-20^{\circ} \mathrm{C}\right)$ for organic chemical analysis (Moore $e t$ al., 1998). Total DNA was extracted using standard methods (Sambrook et al., 1989) as modified by Baker et al. (1991). The sex of individuals was identified by amplification and restriction fragment analysis of the ZFY/ZFX gene, as described by Palsbøll et al. (1992). Analysis of diversity and distribution of mitochondrial DNA (mtDNA) from samples collected in 1995 are reported by Baker et al. (1999).

\section{Group size and behaviour}

Prior to approaching a group of whales the group size and activity were recorded. Animals were considered to be part of a group if they were within one and a half whale lengths of each other and their activities were coordinated. Activities were placed into one of the following categories:

(1) Rest: whale remaining motionless, moving only slightly to breathe.

(2) Travel: directional forward movement that resulted in a change of location.

(3) Social: two or more non-calves interacting at the surface; no attempt was made to differentiate between social activity and sexual activity.
(4) Approached boat: whale altering its course to actively investigate the research vessel.

(5) Play: above surface activity not apparently linked to social activity. This included breaching, pectoral slaps, lobtailing and interactions with kelp.

(6) Feeding: whale travelling at the surface with mouth open.

Attempts were made to randomise sampling by regularly changing location of data collection, zig-zagging within the harbour and attempting to approach each group sighted. An exception was made in the case of cow-calf pairs. In most cases, encounters were terminated when whales showed signs of active avoidance. In 1996 and 1997, encounters with cow-calf pairs were minimised until directed surveys had been completed (see below) to reduce potential disturbance response to boat approaches.

\section{Cow-calf abundance and habitat use}

To estimate the total number of cow-calf pairs in Port Ross, directed surveys were conducted from aboard a motor/sailing vessel in 1996 and 1997. During each survey (two per year), the vessel moved around Enderby and criss-crossed Port Ross and Laurie Harbour (Fig. 1B, Fig. 3) in an attempt to approach every cow-calf pair in the area. Cow-calf pairs were located and photographed by an observer in the spreaders of the mast and a second photographer on deck and the location of all pairs encountered was noted on a map with $1 \mathrm{~km}$ grids (Fig. 3). 
Groups without calves were ignored. In both years the north coast of Enderby Island was not surveyed because of high sea states.

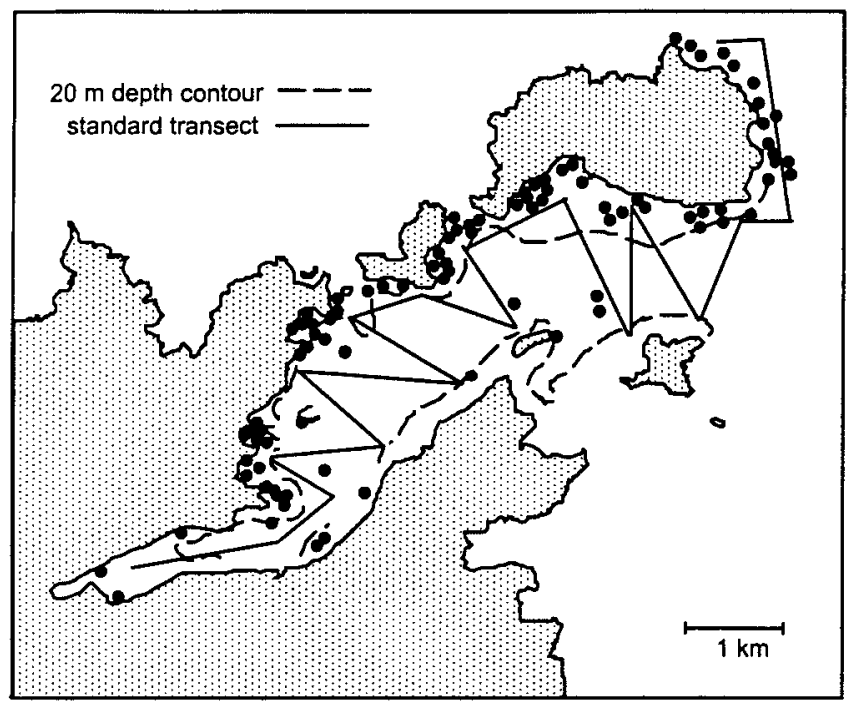

Fig. 3. Locations (filled circles) of all cow-calf pairs sighted during directed surveys conducted in winter, 1996 (3 and 5 August) and winter, 1997 (26 and 31 July).

\section{RESULTS AND DISCUSSION}

\section{Distribution}

During the winters of 1995, 1996 and 1997, whales congregated in Port Ross and nearby waters around Enderby Island and in Matheson Bay (Fig. 1). Observers on the helicopter that surveyed the length of the Auckland Islands in 1996 confirmed that the main aggregation of right whales was limited to Port Ross, despite what appears to be adequate habitat along the eastern coast of the main island. During a small boat survey in 1995, two whales were sighted outside Port Ross, along the northeast coast in Haskell Bay and one whale was sighted in North Harbour along the north coast (Fig 1B). This distribution is consistent with the location of whales reported from a RNZAF flight in 1993 (Donoghue, 1995).

\section{Abundance and residency}

Whales were present in Port Ross in high concentrations throughout the study period (mid-July until the first week in August) in all three years. Minimum abundance estimates from one-day shore- and boat-based counts were conducted in 1995, 1996 and 1997 as shown in Fig. 2. On 6 August 1995 , observers counted a total of 71 groups including at least 87 adults (non-calves) and 9 calves. On 6 August 1996 the count was lower, in part due to poor sighting conditions. Only 50 groups were sighted, including 69 adults and 11 calves. On 28 July 1997, substantially more whales were sighted with 94 groups totalling 128 adults and 18 calves. The between-year variation may be real or may represent a within-season abundance variation, or variation in the ability of the observers to determine group sizes. In 1997, the density of whales was approximately five whales $/ \mathrm{km}^{2}$ in Port Ross.

A total of 217 individual whales have been photo-identified over three years of this study, almost half of which were identified in $1997(n=92 ; n=69$ in 1995; $n=56$ in 1996). The larger proportion of whales identified in 1997 despite the shorter field season (16 days) corresponds to the increased photographic effort in that year. Of the sum total number of animals identified each year $(n=236)$, only $24 \%$ were resighted on subsequent days within a season. When whales were resighted within the 16-23 day field seasons, the average interval between first and last sighting was 6.4 days $(\mathrm{SD}=4.0)$. The longest resighting interval within season extended to the entire 20 day period in 1995. This single adult was photo-identified on 20 July and resighted on the 9 August. About $15 \%$ of whales were identified in two years of the study years and only one whale was identified in all three years.

Although the resightings rate and interval between first and last sightings were constrained by the duration of the field season and photo effort, these seem lower than reported for some other wintering grounds (Bannister, 1990; Burnell and Bryden, 1997). It suggests that some whales are not resident throughout the field season.

\section{Reproduction}

Cow-calf pairs were present throughout the three winter field seasons. The small size of calves, some with the presence of foetal folds and wrinkly skin suggests they were newborn. Based on the three one-day censuses conducted, the number of calves averaged 12\% (range 9-14\%) of the total population. In an attempt to estimate the total number of cow-calf pairs in the area, directed surveys were conducted from aboard a motor/sailing vessel in 1996 and 1997. On 3 August 1996, 20 cow-calf pairs were approached. Two days later, 22 cow-calf pairs were encountered. On 26 July 1997 , 24 cow-calf pairs were sighted and approached. Five days later, 26 cow-calf pairs were encountered.

In total, 43 cows have been photo-identified over three years of this study (12 in 1995, 11 in 1996 and 20 in 1997). This represents a minimum count of the number of mature females in this population. No cow sighted with a calf was resighted in a subsequent year or in the year preceding the birth of its calf. One female sighted in a social group of three in 1995 was resighted in 1997 with a calf.

\section{Group size and activity}

The size and pre-approach activity of groups were recorded on 358 occasions (Table 1). Most groups approached (29\%) were composed of three or more (non-calf) individuals $(n=103)$. About $25 \%$ of non cow-calf groups encountered were single $(n=90)$, and $23 \%$ were in pairs $(n=82)$. Groups containing cow-calf pairs were encountered $23 \%$ of the time $(n=83)$. The largest group observed was a surface-active group of at least 10 individuals.

Most single individuals were found resting at the surface $(59 \%)$. On $19 \%$ of encounters single individuals approached the research vessel and appeared attracted by the sound of the outboard motor in neutral. Travel by non-calf groups was rarely observed (3-10\%). Activity of groups with a calf are considered separately below. Social activity was predominant with groups of three or more (non-calf) whales encountered (83\%). Apparent mating activity was observed on most of these occasions as evidenced by abundant whitewater, erect penises and females exposing their bellies to the surface. Intromission between males and females was observed and documented on film once.

Presumed feeding was rarely observed despite the presence of swarms of munidea sp. On 30 July 1997 a single whale repeatedly surfaced with its mouth open. The film crew also documented a whale travelling underwater with mouth open, apparently pumping water with its tongue. Defecation was never observed. 
Table 1

Frequency of activity of southem right whales in relation to group size and composition. $\mathrm{N}=$ Total observations.

\begin{tabular}{lcccccc}
\hline & \multicolumn{6}{c}{ \% Activity } \\
\cline { 2 - 7 } Group size & Rest* & Travel & Play & Social & Approach \\
boat & $N$ \\
\hline $\begin{array}{l}\text { Single } \\
\text { Pair (excluding }\end{array}$ & 60 & $10^{* *}$ & 11 & - & 19 & 90 \\
$\begin{array}{l}\text { cow-calf pairs) } \\
\text { Group 3-10 }\end{array}$ & 14 & 3 & 0 & 83 & $<1$ & 103 \\
$\begin{array}{l}\text { (excluding cow-calf } \\
\text { pairs) }\end{array}$ & & & & & & 82 \\
Cow-calf pairs & 64 & 36 & 0 & 0 & 0 & 67 \\
$\begin{array}{l}\text { Cow-calf pairs and } \\
\text { other(s) }\end{array}$ & 50 & 13 & 0 & 38 & 0 & 16 \\
\end{tabular}

* For cow-calf pairs, rest referred to the cow, regardless of the activity of the calf.

** One whale was observed swimming back and forth in a rip, presumably feeding.

\section{Sex ratio}

A total of 182 whales were sexed by molecular method. Of these, 96 were males and 86 were females (Table 2). Adults assumed to be cows because of their association with a calf were confirmed to be female $(n=26)$. The percent of females varied from $54 \%$ to $39 \%$ over the three years but the sex ratio did not differ significantly from 1:1 in any year. However, the collection of samples was not random with respect to cow-calf pairs and the ratios could be biased towards cows in some years. It is unknown how many whales are duplicate samples because biopsy samples were not always associated with photo-identification. However, attempts were made to minimise duplicate sampling by biopsying each whale in the same body area and scanning each whale approached for the small biopsy mark prior to sampling. Further analysis at nuclear loci should resolve this.

Table 2

Sex of southern right whales at the Auckland Islands as identified by molecular analysis of skin biopsy samples, 1995-97.

\begin{tabular}{|c|c|c|c|c|c|c|c|c|}
\hline & \multicolumn{2}{|c|}{1995} & \multicolumn{2}{|c|}{1996} & \multicolumn{2}{|c|}{1997} & \multicolumn{2}{|c|}{ Total } \\
\hline & Males & Females & Males & Fem & Male & Fem: & Male & Females \\
\hline Calves & 2 & 2 & 2 & 2 & 1 & 1 & 5 & 5 \\
\hline Non-calves* & 30 & 26 & 22 & 10 & 39 & 19 & 91 & 55 \\
\hline Cows & 0 & 7 & 0 & 13 & 0 & 6 & - & 26 \\
\hline Total & 32 & 35 & 24 & 25 & 40 & 26 & 96 & 86 \\
\hline
\end{tabular}

* Excluding cows.

\section{Cow-calf habitat use}

The majority of sightings of cow-calf pairs during directed surveys were found on the western shore of Laurie Harbour and Port Ross and on the northeast shore of Enderby Island (Figs. 1B and 3). Weather conditions prevented a full survey of the north coast of Enderby Island but several cow-calf pairs were sighted along its northern coast during shore-based observations.

Of the 78 cow-calf pair sightings made in charted depths, $90 \%$ were located in waters less than $20 \mathrm{~m}$ deep and all but three sightings were made within $500 \mathrm{~m}$ of shore. Most groups including a calf $(61 \%)$ were sighted resting at the surface and only $31 \%$ of groups including a calf were observed travelling (Table 1). Several episodes of riding above the mother's back were also observed. When cow-calf pairs were sighted with other whales (19\% of the time), cows spent less time resting (38\%) and spent an increased amount of time socialising at the surface $(38 \%)$. During these occasions, the calf was more often found playing at the surface $(13 \%)$.

On the Peninsula Valdés wintering grounds, Thomas and Taber (1984) reported that travel was the predominant activity for cows and calves during the entire infant period, and specifically characterised the behaviour of newborn calves while play did not begin until calves were one or two months old. We have not made any attempt to categorise the age of calves and, because of the limited duration of the field seasons, made no attempt to characterise the change in cow-calf behaviour over time.

\section{CONCLUSIONS}

The observations collected during the past three field seasons confirm that the Auckland Islands are an important habitat for wintering southern right whales. The total number of photo-identified animals is evidence that the current stock includes at least 217 whales including 43 reproductive females. Whales are concentrated almost exclusively in Port Ross, despite what appears to be adequate habitat to the east and further south. Whales are clearly engaged in behaviour typical of a breeding ground, with most groups engaged in social and sexual activity. Cows give birth in or near Port Ross and seek out shallow nearshore waters for calf rearing.

Re-identification of individual right whales from the Auckland Islands and Campbell Island within and between seasons demonstrates interchange between the two areas, suggesting that the two aggregations are part of a single sub-Antarctic wintering population (Cawthorn, 1990; Patenaude et al., 2001). The low resightings rate within a season and length of residency at the Auckland Islands suggest the possibility of broader movement outside the New Zealand sub-Antarctic. However, significant differences in the distribution of mtDNA lineages indicates that whales wintering in the Auckland Islands are demographically distinct from those wintering along the southwest coast of Australia (Baker et al., 1999). Further research should be directed at determining the genetic relationship between the New Zealand sub-Antarctic population and whales along eastern Australia and Tasmania.

The consistent presence of whales in the sub-Antarctic islands is in marked contrast to the very low levels of sightings along the New Zealand mainland and Kermadec Islands. This suggests that there has been a major shift in habitat use of a single stock or loss of a component of a historically sub-divided stock.

\section{ACKNOWLEDGEMENTS}

The project was funded by grants from the Whale and Dolphin Conservation Society, the US Department of State (Program for Cooperative US/NZ Antarctic Research), the Auckland University Research Council, Shell/WWF New Zealand and the Percy Sladen Memorial Fund. Logistic support was provided by Southland Conservancy, Department of Conservation. We thank G. Ayburn, M. Brabyn, K. Baird, N. Gales, S. Childerhouse, M. Marx, L. Medrano, B. Yung, L. Broberg and the TVNZ Natural History Unit for assistance in the field. We thank S. Kafka for his generosity and the crews of the 'Evohe' and the 'Breaksea Girl' for their assistance. We thank G. Stone, P. 
Hamilton and the New England Aquarium for the loan of biopsy equipment in 1995. M. Cawthorn, S. Kraus and F. Pichler provided constructive comments on this manuscript. M. Cawthorn and R. Stewart provided valuable advice in the early stages of the project. We thank S. Kraus for providing a critical review of the photo-identification catalogue. The manuscript was improved by the comments of two anonymous reviewers.

\section{REFERENCES}

Baker, C.S., Lambertsen, R.H., Weinrich, M.T., Calambokidis, J., Early, G. and O'Brien, S.J. 1991. Molecular genetic identification of the sex of humpback whales (Megaptera novaeangliae). Rep. int. Whal. Commn (special issue) 13:105-11.

Baker, C.S., Patenaude, N.J., Bannister, J.L., Robins, J. and Kato, H. 1999. Distribution and diversity of mtDNA lineages among southern right whales (Eubalaena australis) from Australia and New Zealand. Mar. Biol. 134:1-7.

Bannister, J.L. 1990. Southern right whales off western Australia. Rep. int. Whal. Commn (special issue) 12:279-88.

Brown, M.W., Kraus, S.D. and Gaskin, D.E. 1991. Reaction of North Atlantic right whales (Eubalaena glacialis) to skin biopsy sampling for genetic and pollutant analysis. Rep. int. Whal. Commn (special issue) $13: 81-9$

Burnell, S.R. and Bryden, M.M. 1997. Coastal residence periods and reproduction timing in southern right whales (Eubalaena australis). J. Zool., Lond. 241:613-21.

Cawthorn, M.W. 1978. Whale research in New Zealand. Rep. int. Whal. Commn 28:109-13.

Cawthorn, M.W. 1986. New Zealand. Progress report on cetacean research, May 1984-May 1985. Rep. int. Whal. Commn 36:164-6.

Cawthorn, M.W. 1988. New Zealand. Progress report on cetacean research, May 1986-May 1987. Rep. int. Whal. Commn 38:204.

Cawthorn, M.W. 1990. New Zealand. Progress report on cetacean research, April 1988 to May 1989. Rep. int. Whal. Commn 40:202-5.

Cawthorn, M.W. 1993. New Zealand. Progress report on cetacean research, April 1991 to April 1992. Rep. int. Whal. Commn 43:286-8.

Dawbin, W.H. 1986. Right whales caught in waters around south eastern Australia and New Zealand during the nineteenth and early twentieth centuries. Rep. int. Whal. Commn (special issue) 10:261-7.

Donoghue, M.F. 1995. New Zealand progress report on cetacean research, April 1993-March 1994. Rep. int. Whal. Commn 45:247-50.

Gaskin, D.E. 1964. Return of the southern right whale (Eubalaena australis Desm.) to New Zealand waters, 1963. Tuatara:115-8.

Gaskin, D.E. 1968. The New Zealand Cetacea. Fisheries Research Bulletin No. 1 (New Series) Edn. Fisheries Research Division, New Zealand Marine Department, Wellington. 90pp.
Grady, D. 1986. Sealers \& Whalers in New Zealand. Reed Methuen, Auckland. 307pp.

International Whaling Commission. 1990. Report of the Workshop on Individual Recognition and the Estimation of Cetacean Population Parameters, La Jolla, 1-4 May 1988. Rep. int. Whal. Commn (special issue) 12:3-40.

Kraus, S.D., Moore, K.E., Price, C.A., Crone, M.J., Watkins, W.A., Winn, H.E. and Prescott, J.H. 1986. The use of photographs to identify individual North Atlantic right whales (Eubalaena glacialis). Rep. int. Whal. Commn (special issue) 10:145-51.

Moore, M.J., Miller, C.A., Weisbrod, A.V., Shea, D., Hamilton, P.K., Kraus, S.D., Rowntree, V.J., Patenaude, N. and Stegman, J.J. 1998. Cytochrome P450 1A and chemical contaminants in dermal biopsies of northern and southern right whales. Paper SC/M98/RW24 presented to the IWC Special Meeting of the Scientific Committee towards a Comprehensive Assessment of Right Whales Worldwide, 16-25 March, Cape Town, South Africa. [Available from the Office of this Journal].

Palsbøll, P.J., Vader, A., Bakke, I. and El-Gewely, M.R. 1992. Determination of gender in cetaceans by the polymerase chain reaction. Can. J. Zool. 70:2166-70.

Patenaude, N., Baker, C.S. and Gales, N.J. 1998. Observations of southern right whales on New Zealand's sub-Antarctic wintering grounds. Mar. Mammal Sci. 14(2):350-5.

Patenaude, N., Todd, B. and Stewart, R. 2001. A note on movements of southern right whales between the sub-Antarctic Auckland and Campbell Islands, New Zealand. J. Cetacean Res. Manage. (special issue) 2:121-123.

Payne, R., Brazier, O., Dorsey, E.M., Perkins, J.S., Rowntree, V.J. and Titus, A. 1983. External features in southern right whales (Eubalaena australis) and their use in identifying individuals. pp. 371-445. In: R. Payne (ed.) Communication and Behavior of Whales. AAAS Selected Symposia Series 76. Westview Press, Colorado. xii+643pp.

Richards, R. 1993. Into the South Seas: The Southern Whale Fishery Comes of Age on the Brazil Banks 1765 to 1812. The Paramatta Press, Wellington. 128pp.

Sambrook, J., Fritsch, E.F. and Maniatis, T. 1989. Molecular Cloning: A Laboratory Manual. 2nd Edn. Cold Spring Harbor Laboratory, New York.

Smith, T.D. 1977. A matrix model of sperm whale populations. Rep. int. Whal. Commn 27:337-42.

Stewart, R. and Todd, B. 2001. A note on observations of southern right whales at Campbell Island, New Zealand. J. Cetacean Res. Manage. (special issue) 2:117-120.

Thomas, P.O. and Taber, S.M. 1984. Mother-infant interaction and behavioral development in southern right whales, Eubalaena australis. Behaviour 88(1-2):42-60. [Abstract in Rep. int. Whal. Commn (special issue) 6:485].

Tormosov, D.D., Mikhalev, Y.A., Best, P.B.,Zemsky, V.A., Sekiguchi, K. and Brownell Jr, R.L. 1998. Soviet catches of southern right whales, Eubalaena australis, 1951-1971; biological data and conservation implications. Biol. Conserv. 86:185-97.

Townsend, C.H. 1935. The distribution of certain whales as shown by logbook records of American whaleships. Zoologica (N.Y.) 19(1-2):1-50+6 maps. 